\title{
Parametrization of the Earthquake occurred on May 8, 2021, Florida Department, Uruguay
}

Leda Sánchez Bettucci ${ }^{1,2}$, Judith Loureiro Olivet ${ }^{1,3}$, Hernán Castro ${ }^{1,3}$, Martín Rodríguez ${ }^{1,3}$, Damián Dell'Acqua ${ }^{1}$, Enrique Latorres ${ }^{1,4}$, Anahí Curbelo ${ }^{1,3} .{ }^{1}$ Observatorio Geofísico del Uruguay, ${ }^{2}$ Universidad de la República - Facultad de Ciencias Instituto de Ciencias Geológicas - Departamento de Geodinámica Interna, ${ }^{3}$ Dirección Nacional de Minería y Geología Ministerio de Industria, Energía y Minería, ${ }^{4}$ Universidad ORT.

Copyright 2021, SBGf - Sociedade Brasileira de Geofísica.

This paper was prepared for presentation during the $17^{\text {th }}$ International Congress of the Brazilian Geophysical Society held in Rio de Janeiro, Brazil, $16-19$ August 2021. Contents of this paper were reviewed by the Technical Committee of the $17^{\text {th }}$ International Congress of the Brazilian Geophysical Society and do not necessarily represent any position of the SBGf, its officers or members. Electronic reproduction or storage of any part of this paper for commercial purposes without the written consent of the Brazilian Geophysical Society is prohibited.

\section{Abstract}

On May 8, 2021, an earthquake took place in the northeastern part of the Florida department, located in the central area of Uruguay. This event was perceived by the local population at several localities (Molles del Timote, Capilla del Sauce, Talita, Goñi, Florida, Fray Marcos, Polanco del Yí, among others) as an earthquake with one or two associated rumbling sounds. Within a radius of approx. 50 $\mathrm{km}$ the majority of respondents heard the sound. The seismic event was registered in four stations of the Uruguayan national seismological network. The arrival times of the $\mathrm{P}$ and $\mathrm{S}$ waves represent hypocentral distances between 122 and $216 \mathrm{~km}$. The local magnitudes were calculated for each station, obtaining values between 4.4 and 4.9 and an average of 4.6 . The epicentral location (-33.64 ${ }^{\circ}$ $\pm 0.18,-55.65^{\circ} \pm 0.18$ ) was determined by triangulation based on the difference in time of arrival of the $P$ and $S$ waves at each station. Additionally, the time of origin (11:55:26 UTC) was determined using the epicentral location obtained and the travel time assuming an intermediate crust composition. 